\title{
Electroepoxidation of natural and synthetic alkenes mediated by sodium bromide
}

Massuquinini Inês ${ }^{a}$, António J. Mendonça ${ }^{b, ~}{ }^{*}$, Ana P. Esteves ${ }^{c}$, Dina I. Mendonça ${ }^{\text {, }}$, Maria J. Medeiros ${ }^{\mathrm{c}}$

${ }^{a}$ Departamento de Química, Universidade Agostinho Neto, Luanda, Angola

${ }^{\mathrm{b}}$ Centro de Investigação em Ciências da Saúde e Departamento de Química, Universidade da Beira Interior, R. Marquês d'Ávila e Bolama, 6201-001 Covilhã, Portugal

${ }^{\mathrm{c}}$ Centro de Química, Universidade do Minho, Largo do Paço, 4704-553 Braga, Portugal

${ }^{\mathrm{d}}$ Departamento de Química, Universidade da Beira Interior, R. Marquês d'Ávila e Bolama, 6201-001 Covilhã, Portugal

\begin{abstract}
Electroepoxidation of synthetic alkenes (styrene, trans-stilbene and trans- $\beta$-methylstyrene) and of some natural terpenes (limonene, terpinolene, geraniol, $\alpha$-terpinene, $\gamma$-terpinene and $\alpha$ terpineol) mediated by sodium bromide was performed in $\mathrm{MeCN}: \mathrm{H}_{2} \mathrm{O}$ (4:1) at platinum electrodes. The indirect electrochemical oxidation of the olefins led to the corresponding epoxides in yields ranging from $23 \%$ to $79 \%$.
\end{abstract}

\section{Résumé}

L'électroépoxydation $d$ 'alcènes synthétiques (styrène, trans-stilbène et trans- $\beta$ méthylstyrène) et d'alcènes naturels terpéniques (limonène, terpinolène, géraniol, $\alpha$-terpinène, $\gamma$-terpinène et $\alpha$-terpinéol) à l'aide de bromure de sodium a été réalisée dans un mélange $\mathrm{MeCN}: \mathrm{H}_{2} \mathrm{O}$ (4:1) avec des électrodes de platine. L'oxydation électrochimique indirecte d'oléfines conduit aux époxydes correspondants avec des rendements allant de $23 \%$ à $79 \%$.

Keywords: electrochemical epoxidation; sodium bromide; alkenes; terpenes Mots-clés: epoxydation électrochimie; bromure de sodium; alcènes ; terpènes 
* Corresponding author: Tel.: +351275319822; fax: +351275319730

E-mail address: mendonca@ubi.pt (A.J. Mendonça). 


\section{Introduction}

Epoxides are versatile and valuable intermediates in the synthesis of several biologically active compounds and they play an important role in the industry. The ease of preparation of these compounds and their facile ring-opening reactions have contributed to epoxides an attractive way of functionalising olefins. Some chemical routes to produce epoxides use reagents such as organic peroxyacids [1], sodium hypochlorite [2] or hydrogen peroxide [3] as a source of oxygen. The use of these reagents in the presence of a variety of catalysts, to synthesize epoxides has also been reviewed recently [4].

Electrochemical methodology has been investigated as a promising alternative route to epoxides motivated by the inherent advantages of ease of operation and limited environmental impact [5]. Moreover, indirect electrochemical reactions in comparison with direct electrochemical reactions present, in general, important advantages such as: low consumption of electricity; improvement of yield; an increase of reaction rate; reaction of electrochemically inactive substrates, by decrease of activation energy [6]. The high industrial demand for epoxides has led to a need for a "greener" route for its production. It was reported [5a] that electrogenerated hydrogen peroxide in ionic liquids, under a carbon dioxide-saturated environment and in the presence of a catalytic amount of a manganese salt, was used in the epoxidation of lipophilic alkenes. Allylic alcohols were successfully electroepoxidized by means of hydrogen peroxide generated in situ in the presence of titanium silicalite-1 [5b]. Electrosynthesis of epoxides and dibromides from olefinic carboxylic acids was achieved [7] by indirect oxidation (bromination) through a $\mathrm{Br}^{-} / \mathrm{Br}^{+}$mediator leading to the corresponding 1,2-dibromide. The epoxidation was obtained by a multi-step process involving the cathodic reduction of dioxygen to hydrogen peroxide and also the action of a vanadium catalyst. Electroepoxidation can also be achieved by bromide ion mediation [8] at room temperature. 
The reaction proceeds through an indirect electrochemical reaction avoiding certain specific disadvantages of direct electrolysis for example in passivation of the electrode surface or slow heterogeneous electron transfer. Tori et al. [9] reported that the electrooxidation of halide salts is useful for the generation of reactive species of halogen atoms under mild conditions. In fact, it has been shown that the $\mathrm{Br}^{-}$ion discharged from $\mathrm{NaBr}$ can be a good mediator for the epoxidation of dimethyl 4-cyclohexene-1,2-dicarboxylate and acyclic alkenes [9] and $n$ hexene [10] in water-organic solvent media.

Herein, using the methodology reported in the literature [9], we describe the electrochemical epoxidation of styrene, $(E)$-1,2-diphenylethene (trans-stilbene), 1-[(E)-prop1-enyl]benzene (trans- $\beta$-methylstyrene), 1-methyl-4-(prop-1-en-2-yl)cyclohex-1-ene (limonene), 1-methyl-4-(propan-2-ylidene)cyclohex-1-ene (terpinolene), (E)-3,7dimethylocta-2,6-dien-1-ol (geraniol), 1-isopropyl-4-methylcyclohexa-1,3-diene $\quad(\alpha-$ terpinene), 1-isopropyl-4-methylcyclohexa-1,4-diene ( $\gamma$-terpinene) and 2-(4-methylcyclohex3-enyl)propan-2-ol ( $\alpha$-terpineol), and using sodium bromide as mediator in acetonitrile-water mixtures at constant current electrolyses. The yields obtained are compared with those published for the epoxidation of the same alkenes using different methodologies.

\section{Results and Discussion}

\subsection{Electrochemistry of $\mathrm{Br}_{2} / \mathrm{Br}^{-}$system}

The cyclic voltammetric study of $\mathrm{Br}_{2} / \mathrm{Br}^{-}$system was carried out in $\mathrm{MeCN}: \mathrm{H}_{2} \mathrm{O}$ (1:4)

containing $\mathrm{NaClO}_{4}\left(0,1 \mathrm{~mol} \cdot \mathrm{dm}^{-3}\right)$ as supporting electrolyte at a platinum electrode. Under these conditions the $\mathrm{Br}^{-}$ion presents an oxidation peak at $0.99 \mathrm{~V}$ and the corresponding 
reduction peak at $0.91 \mathrm{~V}$ vs $\mathrm{Ag} / \mathrm{AgCl}$ due to the one-electron process described in the following equation:

$$
\mathrm{Br}^{-} \rightleftharpoons 1 / 2 \mathrm{Br}_{2}+1 \mathrm{e}^{-}
$$

By addition of 5 equivalents of alkene to the $\mathrm{NaBr}$ solution, it was also observed that the current intensity for the oxidation of $\mathrm{Br}^{-}$ion increased slightly and that the cathodic peak for the $\mathrm{Br}_{2}$ reduction disappeared. Similar results were reported by Nematollahi et al. [11].

2.2 Electroepoxidation of synthetic alkenes: styrene, (E)-1,2-diphenylethene and 1-[(E)-prop1-enyl]benzene

The study was initiated by carrying out constant-current electrolysis of $20 \mathrm{mM}$ styrene (1) in the presence of $20 \mathrm{mM} \mathrm{NaBr}$ as mediator using a current density of $33 \mathrm{~mA} \mathrm{~cm}$ and $\mathrm{Pt}$ electrodes in $\mathrm{MeCN}: \mathrm{H}_{2} \mathrm{O}$ (4:1). It was observed, based on ${ }^{1} \mathrm{H}-\mathrm{NMR}$ data [12], that 2phenyloxirane (4) was obtained in $27 \%$ yield (Table 1 , entry 1 ). In order to improve the yield of epoxide we studied the influence of the concentration of $\mathrm{NaBr}$ and found that an increase from $20 \mathrm{mM}$ to $30 \mathrm{mM}$ led to an increase in the yield of 4 to $57 \%$ (Table 1, entry 2). The influence of the current density was also explored and an increase from 33 to $66 \mathrm{~mA} \mathrm{~cm}^{-2}$ was found to produce the epoxide, as the major product, in a yield of $79 \%$ (Table 1, entry 3 ), together with bromohydrin $3(10 \%)$ and dibromo derivative $6(11 \%)$ as by-products (Fig.1). These products were identified on the basis of ${ }^{1} \mathrm{H}-\mathrm{NMR}$ data. In previous studies [13] it was reported that styrene oxide was obtained in yields between 30 and $100 \%$ using constant-potential electrolyses and Mn-Salen catalysts.

Electroepoxidation of (E)-1,2-diphenylethene (8) was carried out using the same experimental conditions and a current density of $33 \mathrm{~mA} \mathrm{~cm}^{-2}$ and led to the formation of 2,3diphenyloxyrane (9) in $23 \%$ yield (Table 1 , entry 4 ). The main by-product identified was the 
corresponding dibromide 10 (16\%) (Fig. 2). Using the same current density but increasing the charge passed, the degree of conversion increased but the epoxide yield did not (Table 1, entry 5). Subsequently, the influence of the current density was studied and it was found that using a current density of $3.3 \mathrm{~mA} \mathrm{~cm} \mathrm{~cm}^{-2}$, the electroepoxidation of $(E)$-1,2-diphenylethene (8) led to the formation of 2,3-diphenyloxyrane (9) in 38\% yield (Table 1, entry 6). An epoxide yield between $70 \%$ and $93 \%$ was obtained with cobalt catalysts or potassium peroxomonosulfate [14].

The electroepoxidation of 1-[(E)-prop-1-enyl]benzene (11) was performed using the same experimental conditions and a current density of $33 \mathrm{~mA} \mathrm{~cm}{ }^{-2}$. Under these conditions a conversion of $100 \%$ of 1-[(E)-prop-1-enyl]benzene was obtained (11) but 2-methyl-3phenyloxirane (12) was produced with $30 \%$ yield and a current efficiency of $29 \%$ (Fig. 3) (Table 1, entry 7). Epoxide (12) was obtained in 5-54\% yield when Ni(II) complexes were used as catalysts [15].

In all the epoxidations carried out the main by-products obtained were the corresponding bromohydrin (4 - 23\%) and dibromide (11\% - 20\%) derivatives. In agreement with Alkire and Köhler [10] the bromohydrin precedes the formation of epoxide while dibromide formation prevents the formation of epoxide.

2.3 Electroepoxidation of monoterpenes: 1-methyl-4-(prop-1-en-2-yl)cyclohex-1-ene, 1methyl-4-(propan-2-ylidene)cyclohex-1-ene, (E)-3,7-dimethylocta-2,6-dien-1-ol, 1-isopropyl4-methylcyclohexa-1,3-diene, 1-isopropyl-4-methylcyclohexa-1,4-diene, and 2-(4methylcyclohex-3-enyl)propan-2-ol

The terpene epoxides are important building blocks for natural products synthesis and as starting materials in the synthesis of flavours, fragrances and therapeutically active substances 
[16]. The electrochemical epoxidation was performed by slightly modifying the experimental conditions (see conditions in Table 2 caption) used for the electroepoxidation of synthetic alkenes. The results obtained are presented in Table 2 .

\section{1-methyl-4-(prop-1-en-2-yl)cyclohex-1-ene}

The constant current electrolysis of 1-methyl-4-(prop-1-en-2-yl)cyclohex-1-ene (13) (20 $\mathrm{mM})$ in $\mathrm{MeCN}: \mathrm{H}_{2} \mathrm{O}(4: 1)$ as substrate in the presence of $\mathrm{NaBr}(40 \mathrm{mM})$, with a current density of $33 \mathrm{~mA} . \mathrm{cm}^{-2}$ using Pt electrodes $\left(1.1 \times 1.1 \mathrm{~cm}^{2}\right)$, after $5 \mathrm{~F} / \mathrm{mol}$, produced an unexpected compound (15) in 25\% yield (Fig. 4). The structure proposed for compound 15 was derived from the NMR $\left({ }^{1} \mathrm{H}\right.$ and $\left.{ }^{13} \mathrm{C}\right)$ analysis and is in agreement with the literature [17]. This compound was obtained when the concentration of 1-methyl-4-(prop-1-en-2yl)cyclohex-1-ene was half of the concentration of $\mathrm{NaBr}$ and the current density was 33 $\mathrm{mA} \cdot \mathrm{cm}^{-2}$. Maintaining this current density but increasing the 1-methyl-4-(prop-1-en-2yl)cyclohex-1-ene concentration to $40 \mathrm{mM}$, only compound 14 was obtained in $25 \%$ yield (Table 2, entry 1). The ${ }^{1} \mathrm{H}-\mathrm{NMR}$ spectrum of compound this compound was in good agreement with that already published [12].

In order to study the influence of the current density, the electroepoxidation of 1-methyl-4(prop-1-en-2-yl)cyclohex-1-ene was performed using a current density of $3.3 \mathrm{~mA} \cdot \mathrm{cm}^{-2}$. It was observed that a decrease in the current density reduced the rate of electrolysis and $11 \mathrm{~h}$ were necessary to achieve $3 \mathrm{~F} / \mathrm{mol}$ (Table 2 , entry 2). The Pt electrode area was increased to $2.5 \times 2.5 \mathrm{~cm}^{2}$ and although the reaction time diminished (2.5 hours) and the degree of conversion (93\%) was higher, an epoxide yield of only 34\% was obtained (Table 2, entry 3 ). The analysis of these results confirms that the epoxide was obtained in relatively low yields. It was reported [18] that the electroepoxidation of 1-methyl-4-(prop-1-en-2-yl)cyclohex-1-ene catalysed by $\mathrm{Mn}($ salen), $\mathrm{Ni}($ salen) or heteropolytungstates complexes afforded the expected 
epoxide (14) in 96\% yield in optimised experimental conditions. The analysis of ${ }^{1} \mathrm{H}-\mathrm{RMN}$ spectral data of compound 14 revealed the existence of two diastereomers in the ratio of 3:2.

\section{1-methyl-4-(propan-2-ylidene)cyclohex-1-ene}

The electro-epoxidation of 1-methyl-4-(propan-2-ylidene)cyclohex-1-ene (16) was also mediated by $\mathrm{NaBr}$ in $\mathrm{MeCN}: \mathrm{H}_{2} \mathrm{O}$ (4:1) (Fig. 5) using the optimized conditions applied in 1methyl-4-(prop-1-en-2-yl)cyclohex-1-ene epoxidation. The 2,2,6-trimethyl-1oxaspiro[2.5] oct-5-ene (17) was obtained in $40 \%$ yield with a current efficiency of $45 \%$ for a conversion of $86 \%$ (Table 2 , entry 4 ). The yield obtained is similar to that reported $(36 \%)$ when alumina was used as a heterogeneous catalyst and hydrogen peroxide as the oxidising agent [16].

\section{(E)-3,7-dimethylocta-2,6-dien-1-ol}

The electroepoxidation of (E)-3,7-dimethylocta-2,6-dien-1-ol (18) mediated by NaBr led to the formation of (E)-3-methyl-5-(3,3-dimethyloxiran-2-yl)pent-2-en-1-ol (19) and \{3-methyl3-[2-(3,3-dimethyloxiran-2-yl)ethyl]oxiran-2-yl\}methanol (20) as the main products (Fig. 6). (E)-3-methyl-5-(3,3-dimethyloxiran-2-yl)pent-2-en-1-ol (19) was obtained in 43\% yield and with a current efficiency of $65 \%$ (Table 2 , entry 5). The influence of the charge passed during the reaction was studied in order to improve the yield of 19 but it was observed that by increasing the charge passed (5 F/mol) the yield of (E)-3-methyl-5-(3,3-dimethyloxiran-2yl)pent-2-en-1-ol decreased and that of \{3-methyl-3-[2-(3,3-dimethyloxiran-2yl)ethyl]oxiran-2-yl \}methanol (20) increased (Table 2, entry 6). Comparing these results with those published [19] it can be seen that the yield of (E)-3-methyl-5-(3,3-dimethyloxiran-2yl)pent-2-en-1-ol (19) is lower than that obtained (67\%) with titanosilicates and hydrogen peroxide. However, using the electrochemical approach it is possible to obtain the diepoxide. 
The analysis of ${ }^{13} \mathrm{C}-\mathrm{NMR}$ data of compound 20 reveals a mixture of two diastereomers with a diastereomeric ratio of 3:1 which is in agreement with the published data [20].

\section{Other natural monoterpenes}

We have also performed the electroepoxidation of 1-isopropyl-4-methylcyclohexa-1,3diene (21) (Fig. 7) and compound 22 was obtained in 32\% yield (Table 2, entry 7). A migration of the double bond, via an $\mathrm{S}_{N} 2$ type mechanism was observed. Due to the high reactivity of 1-isopropyl-4-methylcyclohexa-1,3-diene, Uguina et al. [16] also obtained a larger amount of secondary products resulting in a low selectivity in the formation of the epoxide.

In the 1-isopropyl-4-methylcyclohexa-1,4-diene (23) epoxidation (Fig. 8) the epoxide (24) was obtained in a yield of $41 \%$ with a conversion of $82 \%$ (Table 2, entry 8 ). Sakaguchi et al. [21] have reported that the epoxide $\mathbf{2 4}$ could be obtained in a yield of $78 \%$, with aqueous hydrogen peroxide and peroxotungstophosphate as catalyst under biphasic conditions using chloroform as the solvent.

In the case of 2-(4-methylcyclohex-3-enyl)propan-2-ol (25), the conversion of the substrate was $83 \%$ and the epoxide 26 (Fig. 9) yield was 56\% with a current efficiency of $61 \%$ (Table 2, entry 9). Chan et al. [20b] have reported yields of epoxide $\mathbf{2 6}$ in the range $62 \%$ - $86 \%$ using a beta-cyclodextrin-substituted dioxirane as catalyst.

\subsection{Turn-over of NaBr mediator solution}

The turn-over number of the $\mathrm{NaBr}$ aqueous solution to mediate a new electroepoxidation was evaluated using 1-methyl-4-(prop-1-en-2-yl)cyclohex-1-ene as substrate. After removal of the oxidation products (Table 2 , entry 3 ), the $\mathrm{NaBr}$ solution was used for a $2^{\text {nd }}$ run. This 
process was repeated for four runs. The results obtained are presented in table 3. From an analysis of the data reported in Table 3, it is clear that the epoxide yield obtained decreased substantially from the $3^{\text {rd }}$ to the $4^{\text {th }}$ run. From the $1^{\text {st }}$ to the $2^{\text {nd }}$ run there is also a small decrease in the epoxide yield. In each cycle of the mediator there are bromine losses, mainly by the formation of brominated by-products. As the $\mathrm{NaBr}$ concentration diminishes the epoxide yield also decreases. We considered that the yield obtained in the initial experiment (Table 2, entry 3), (34\%) is close to the $39 \%$ obtained in the first run (Table 3, entry 1$)$. We have concluded that the same $\mathrm{NaBr}$ solution can be used at least two further times after the initial electrolysis without significant loss of activity of $\mathrm{NaBr}$.

Taking into consideration our results for the electrochemical epoxidation in the presence of $\mathrm{NaBr}$ and based on the mechanism proposed by $\mathrm{R}$. Alkire et al. [10], we propose the following mechanism.

The initial steps are anodic oxidation of bromide and cathodic reduction of water:

$$
\begin{aligned}
& 2 \mathrm{Br}^{-} \longrightarrow \mathrm{Br}_{2}+2 \mathrm{e}^{-} \\
& 2 \mathrm{H}_{2} \mathrm{O}+2 \mathrm{e}^{-} \longrightarrow \mathrm{H}_{2}+\mathrm{OH}^{-}
\end{aligned}
$$

Subsequently, the molecular bromine reacts with the alkene to form an unstable bromonium intermediate which, through subsequent nucleophilic addition of a hydroxide ion, forms the correspondent bromohydrin, the desired primary product:<smiles>[R]C([R8])=C([R])[NH2+][CH]CC</smiles>

The halohydrin then consumes another $\mathrm{OH}^{-}$ion and is converted to the epoxide:<smiles>[R]C([R])(O)C([R])([R])Br</smiles> 


\section{Conclusion}

The epoxidation of synthetic alkenes and natural terpenes was achieved through an indirect electrochemical reaction, at constant current, mediated by $\mathrm{NaBr}$ in $\mathrm{MeCN}: \mathrm{H}_{2} \mathrm{O}(4: 1)$ at room temperature in an undivided cell under stirring using platinum electrodes $(2.5 \times 2.5$ $\mathrm{cm}^{2}$ or $1.1 \times 1.1 \mathrm{~cm}^{2}$ ). By adjusting the experimental conditions it was possible to obtain the desired epoxides, although other oxidation products can be formed.

Optimised experimental conditions were established with styrene as substrate. The electroepoxidation of all other substrates was carried out using these conditions with minor modifications.

There are several reasons that may explain the relatively low epoxide yields obtained. Epoxides are known to present high reactivity leading them to form other compounds, particularly, diols. In the present study diols were detected by ${ }^{13} \mathrm{C}$ NMR as by-products in all reactions but were not quantified. A further reason for low yields might be a result of the electrophilic addition reaction of bromine to double bonds. This reaction explains the formation of mono-and dibromide by-products. The low yield of monoterpenes epoxides might be explained by the high volatility of these compounds.

However, although the yields are modest, this method may provide an alternative to classical chemical methods, avoiding the use of oxidants such as $\mathrm{NaClO}$. The method used in this study is simple, economic and carried out at room temperature.

\section{Experimental part}

\subsection{Reagents}


Alkenes and monoterpenes were used as received (Sigma-Aldrich, >98\%) and all solvents were purified prior to use.

\subsection{Constant-current electrolysis}

Electrolyses were carried out in a single compartment cell with electrodes separated by 5 mm, under agitation at constant current using a DC power supply (Good Will Instruments GSP-3030D). Electrolyte volumes were $25 \mathrm{~cm}^{3}$ or $50 \mathrm{~cm}^{2}$, using $1.1 \times 1.1 \mathrm{~cm}^{2}$ or $2.5 \times 2.5$

$\mathrm{cm}^{2} \mathrm{Pt}$ electrodes, respectively. The electrolysis was monitored by TLC and terminated when the substrate was completely converted or the number of by-products increased with time without further consumption of the substrate. After the electrolysis, sodium metabissulfite (1\%) was added to the reaction mixture, which was extracted with ethyl ether or chloroform $(3 \times 15 \mathrm{~mL})$ and washed with water. The combined organic extracts were dried $\left(\mathrm{Na}_{2} \mathrm{SO}_{4}\right)$ and concentrated. The crude residue was submitted to flash chromatography on silica gel $60 \mathrm{M}$ (230-400 mesh).

${ }^{1} \mathrm{H}$ and ${ }^{13} \mathrm{C}-\mathrm{NMR}$ data were recorded on a Brucker AC 250P Spectrometer in $\mathrm{CDCl}_{3}$; chemical shifts were measured, in ppm, versus the residual peak of the solvent. The infrared spectra were recorded on a Unicam Mattson 5000 FT spectrophotometer, using capillary films supported on $\mathrm{NaCl}$ windows or on a Bomem MB-series FT-IR/DiffusIR spectrophotometer, using Nujol mulls on $\mathrm{NaCl}$ windows.

The compounds were identified by means of ${ }^{1} \mathrm{H}$ NMR $\left(250 \mathrm{MHz}, \mathrm{CDCl}_{3}\right)$ and ${ }^{13} \mathrm{C} \mathrm{NMR}$ (63 MHz) spectrometry, $\delta$ ppm: 
2-phenyloxirane (4). ${ }^{1} \mathrm{H}$ NMR $\left(\mathrm{CDCl}_{3}, 250 \mathrm{MHz}\right): 7.40-7.27$ (5H, m, ArH); 3.83 (1H, dd, $J_{1}$ $\left.=3.9 ; J_{2}=2.5 \mathrm{~Hz}, \mathrm{H}-2\right) ; 3.12\left(1 \mathrm{H}, \mathrm{dd}, J_{1}=5.4 ; J_{2}=3.9 \mathrm{~Hz}, \mathrm{H}-1,\right) ; 2.77\left(1 \mathrm{H}, \mathrm{dd}, J_{1}=5.4 ; J_{2}=\right.$ $2.5 \mathrm{~Hz}, \mathrm{H}-1)$.

2,3-diphenyloxyrane (9). ${ }^{1} \mathrm{H}$ NMR $\left(\mathrm{CDCl}_{3}, 250 \mathrm{MHz}\right)$ : 7.56-7.36 (10H, m, ArH); 3.99 (2H,

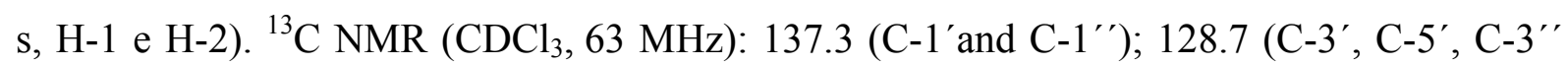
and C-5' '); 128,5 (C-4' and C-4' '); 125,7 (C-2', C-6', C-2'" and C-6"' ); 63,0 (C-1 e C-2).

2-methyl-3-phenyloxirane (12). ${ }^{1} \mathrm{H}$ NMR $\left(\mathrm{CDCl}_{3}, 250 \mathrm{MHz}\right): 7.41-7.21$ (5H, m, ArH); 5.04 $(1 \mathrm{H}, \mathrm{d}, J=10.0 \mathrm{~Hz}, \mathrm{H}-2) ; 4.60\left(1 \mathrm{H}, \mathrm{dq}, J_{1}=10.0 ; J_{2}=6.5 \mathrm{~Hz}, \mathrm{H}-1\right) ; 2.05(3 \mathrm{H}, \mathrm{d}, J=6.5 \mathrm{~Hz}$, $\left.\mathrm{H}-1^{\prime}\right) .{ }^{13} \mathrm{C}$ NMR $\left(\mathrm{CDCl}_{3}, 63 \mathrm{MHz}\right): 140.7$ (C-1' $) ; 128.9\left(\mathrm{C}-4^{\prime \prime}\right) ; 128.8$ (C-3"' and C-5' $)$; $127.8\left(\mathrm{C}-2^{\prime \prime}\right.$ and C-6"'); $59.3(\mathrm{C}-2) ; 51.3(\mathrm{C}-1) ; 26.0\left(\mathrm{C}-1^{\prime}\right) . v_{\max }\left(\mathrm{cm}^{-1}\right): 2923,2852,1560$, 1260 and 840 (C-O-C), 1215, 1094, 820.

1-methyl-4-(prop-1-en-2-yl)-7-oxa-bicyclo[4.1.0]heptane (14). ${ }^{1} \mathrm{H} \quad \mathrm{NMR} \quad\left(\mathrm{CDCl}_{3}, 250\right.$ MHz): 4.65 (2H, br s, H-10); 3.05 (0.4H, t, $J=2.4 \mathrm{~Hz}, \mathrm{H}-2) ; 2.99(0.6 \mathrm{H}, \mathrm{d}, J=5.4 \mathrm{~Hz}, \mathrm{H}-2$ ); 2.18-1.97 (1H, m, H-4); 1.87-1.81 (2H, m, 1H-6 and 1H-3); 1.74-1.50 (2H, m, 1H-5 and 1H3); $1.68(1.2 \mathrm{H}, \mathrm{s}, \mathrm{H}-9) ; 1.66(1.8 \mathrm{H}, \mathrm{s}, \mathrm{H}-9) ; 1.41-1.20(2 \mathrm{H}, \mathrm{m}, 1 \mathrm{H}-5$ and $1 \mathrm{H}-6), 1.31(1.8 \mathrm{H}, \mathrm{s}$, H-7); 1.29 (1.2H, s, H-7).

7-(hydroxymethyl)-4,7-dimethyl-6-oxabicyclo[3.2.1] octan-4-ol (15). ${ }^{1} \mathrm{H} \mathrm{NMR}\left(\mathrm{CDCl}_{3}, 250\right.$ MHz): $3.87\left(1 \mathrm{H}, \mathrm{d}, J=11.1 \mathrm{~Hz}, \mathrm{C}_{2}-\mathrm{OH}\right.$ part A of an AB system, $\left.\mathrm{H}-8\right) ; 3.86(1 \mathrm{H}, \mathrm{d}, J=4.8$ $\mathrm{Hz}, \mathrm{H}-5) ; 3.64\left(1 \mathrm{H}, \mathrm{d}, J=11.1 \mathrm{~Hz}, \underline{\mathrm{C}}_{2}-\mathrm{OH}\right.$ part B of an AB system, $\left.\mathrm{H}-8\right) ; 2.05-1.98(1 \mathrm{H}, \mathrm{m}$, $\mathrm{H}-1)$; 1.86-1.61 (6H, m, H-2, H-3 and H-10); 1.29 (3H, s, H-9); 1.22 (3H, s, H-11). ${ }^{13} \mathrm{C}$ NMR $\left(\mathrm{CDCl}_{3}, 63 \mathrm{MHz}\right): 84.8(\mathrm{C}-5) ; 84.3(\mathrm{C}-7) ; 72.5(\mathrm{C}-4) ; 65.8\left(\underline{\mathrm{CH}}_{2}-\mathrm{OH}\right) ; 40.1(\mathrm{C}-1) ; 35.6$ (C-3 or C-8); 33.8 (C-8 or C-3); 24.5 (C-9 or C-11); 24.4 (C-9 or C-11); 24.2 (C-2).

2,2,6-trimethyl-1-oxaspiro[2.5] oct-5-ene (17). ${ }^{1} \mathrm{H} \mathrm{NMR}\left(\mathrm{CDCl}_{3}, 250 \mathrm{MHz}\right): 5.30$ (1H, dq, $J_{1}$ $\left.=3.1 ; J_{2}=1.6 \mathrm{~Hz}, \mathrm{H}-2\right) ; 2.33-1.96(4 \mathrm{H}), 1.74-1.67(2 \mathrm{H}), 1.65(3 \mathrm{H}, \mathrm{m}, \mathrm{H}-7) ; 1.31$ and 1.28 (6H, 2s, H-10 and H-9). ${ }^{13} \mathrm{C}$ NMR (CDCl 3 , $\left.63 \mathrm{MHz}\right): 134.4$ (C-1); 119.2 (C-2); 64.4 (C-4); 
62.4 (C-8); 30.7 (C-6); 28.9 (C-3); 27.0 (C-5); 23.4 (C-7); 20.9 (C-9); 20.5 (C-10). v $v_{\max }\left(\mathrm{cm}^{-}\right.$ $\left.{ }^{1}\right): 3018(\mathrm{C}=\mathrm{CH}), 2925,2915,1635,1221$ and $852(\mathrm{C}-\mathrm{O}-\mathrm{C}), 756$.

(E)-3-methyl-5-(3,3-dimethyloxiran-2-yl)pent-2-en-1-ol (19). ${ }^{1} \mathrm{H} \mathrm{NMR}\left(\mathrm{CDCl}_{3}, 250 \mathrm{MHz}\right)$ : $5.39(1 \mathrm{H}, \mathrm{t}, J=6.8 \mathrm{~Hz}, \mathrm{H}-2), 4.08(2 \mathrm{H}$, broad d, $J=6.8 \mathrm{~Hz}, \mathrm{H}-1) ; 2.67(1 \mathrm{H}, \mathrm{t}, J=6.2 \mathrm{~Hz}, \mathrm{H}-$ 6); $2.17(1 \mathrm{H}$, broad s, OH); 2.13-2.05 (2H, m, H-4); 1.63 (3H, broad s, H-10); 1.60-1.55 (2H, m, H-5); 1.25 and 1.21 (6H, 2s, H-8 and H-9). ${ }^{13} \mathrm{C} \mathrm{NMR}\left(\mathrm{CDCl}_{3}, 63 \mathrm{MHz}\right): 137.7$ (C-3); 124.2 (C-2); 64.1 (C-6); 58.8 (C-1); 58.5 (C-7); 36.2 (C-4); 27.0 (C-5); 24.7 (C-8); 18.6 (C9); $16.1(\mathrm{C}-10)$.

\{3-methyl-3-[2-(3,3-dimethyloxiran-2-yl)ethyl]oxiran-2-yl\} methanol (20). ${ }^{1} \mathrm{H}$ NMR $\left(\mathrm{CDCl}_{3}, 250 \mathrm{MHz}\right): 3.80-3.68(2 \mathrm{H}, \mathrm{m}, \mathrm{H}-1) ; 2.99\left(1 \mathrm{H}, \mathrm{dd}, J_{1}=8.3 ; J_{2}=3.8 \mathrm{~Hz}, \mathrm{H}-2\right) ; 2.78-$ 2.64 (2H, m, H-6); 1.93 (1H, s, O프); 1.88-1.47 (4H, m, H-4 and H-5); 1.33 (0.75H, H-8); 1.32 (2.25H, H-8); 1.29 and 1.27 (6H, 2s, H-10 and H-9). $\left.{ }^{13} \mathrm{C} \mathrm{NMR} \mathrm{(} \mathrm{CDCl}_{3}, 63 \mathrm{MHz}\right): 64.5$ and $63.9(\mathrm{C}-6) ; 62.9$ and $62.5(\mathrm{C}-2) ; 61.4$ and $61.0(\mathrm{C}-1)$; 60.9 and $60.8(\mathrm{C}-7) ; 59.0$ and 58.7 (C-3); 36.3 and 35.2 (C-4); 24.9 and 24.6 (C-5); 25.0 (C-8); 18.9 and 18.8 (C-9); 17.1 and $16.5(\mathrm{C}-10)$.

1-isopropyl-4-methyl-7-oxa-bicyclo[2.2.1]hept-2-ene (22). ${ }^{1} \mathrm{H} \mathrm{NMR}\left(\mathrm{CDCl}_{3}, 250 \mathrm{MHz}\right)$ : $5.72\left(1 \mathrm{H}, \mathrm{dd}, J_{1}=10.0 ; J_{2}=1.4 \mathrm{~Hz}, \mathrm{H}-2\right) ; 5.61\left(1 \mathrm{H}, \mathrm{dd}, J_{1}=10.0 ; J_{2}=1.5 \mathrm{~Hz}, \mathrm{H}-3\right) ; 1.31(3 \mathrm{H}$, s, H-1' '); $0.96\left(3 \mathrm{H}, \mathrm{d}, J=6.8 \mathrm{~Hz}, \mathrm{H}-2^{\prime}\right) ; 0.89\left(3 \mathrm{H}, \mathrm{d}, J=6.9 \mathrm{~Hz}, \mathrm{H}-3^{\prime}\right) .{ }^{13} \mathrm{C} \mathrm{NMR}\left(\mathrm{CDCl}_{3}, 63\right.$ MHz): 135.5 (C-3); 133.6 (C-2); 71.7 (C-4); 67.4 (C-1); 37.5 (C-1' ); 33.6 (C-5); 29.7 (C-1' '); $27.1(\mathrm{C}-6) ; 17.7$ (C-2'" or C-3); 16.5 (C-3' or C-2').

4-isopropyl-1-methyl-7-oxa-bicyclo[4.1.0]hept-3-ene (24). ${ }^{1} \mathrm{H} \mathrm{NMR}\left(\mathrm{CDCl}_{3}, 250 \mathrm{MHz}\right)$ : $5.15\left(1 \mathrm{H}, \mathrm{dd}, J_{1}=3.4 ; J_{2}=1.9 \mathrm{~Hz}, \mathrm{H}-5\right) ; 3.10(1 \mathrm{H}, \mathrm{br} \mathrm{s}, \mathrm{H}-2) ; 2.13(1 \mathrm{H}$, sept, $J=6.8 \mathrm{~Hz}, \mathrm{H}-$ 8); 1.35 (3H, s, H-7); 0.97 (3H, d, $J=6.8 \mathrm{~Hz}, \mathrm{H}-9) ; 0.96(3 \mathrm{H}, \mathrm{d}, J=6.8 \mathrm{~Hz}, \mathrm{H}-10) .{ }^{13} \mathrm{C}$ NMR $\left(\mathrm{CDCl}_{3}, 63 \mathrm{MHz}\right): 137.7$ (C-4); 113.9 (C-5); 60.4 (C-2); 56.6 (C-1); 34.6 (C-8); 30.6 (C-6); 
27.2 (C-3); 23.0 (C-7); 21.4 (C-9 or C-10); 21.1 (C-10 or C-9). $v_{\max }\left(\mathrm{cm}^{-1}\right): 2948,2879,1640$, 1224 and 845 (C-O-C), 750.

2-(6-methyl-7-oxa-bicyclo[4.1.0]heptan-3-yl)propan-2-ol (26). ${ }^{1} \mathrm{H} \quad \mathrm{NMR} \quad\left(\mathrm{CDCl}_{3}, 250\right.$ MHz): $2.92(1 \mathrm{H}, \mathrm{d}, J=5.3 \mathrm{~Hz}, \mathrm{H}-2)$; 2.14-1.42 (6H, m, H-3, H-6 and H-5); 1.70-1.51 (1H, m,

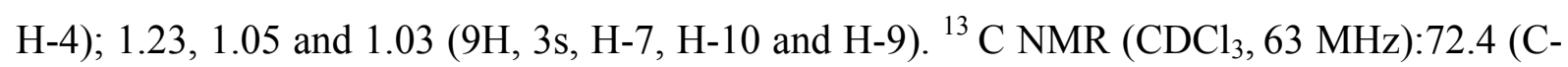
8); 59.3 (C-2); 57.8 (C-1); 44.1 (C-4); 30.8 (C-6); 27.3 (C-7); 26.1 (C-9 or C-10); 25.9 (C-3); 24.4 (C-10 or C-9).

\section{Acknowledgements}

One of the authors (M. I.) gratefully acknowledges a GRICES PhD scholarship and INABE (Angola) for financial support.

\section{References}

[1] A.P. James, R.A.W. Johnstone, M. McCarron, J.P. Sankey, B. Trenbirth, Chem. Commun. 3 (1998) 429.

[2] M. Klawonn, S. Bhor, G. Mehltretter, C. Döbler, C. Fischer, M. Beller, Adv. Synth. Catal. $345(2003) 389$.

[3] N.A. Stephenson, A.T. Bell, J. Mol. Cat. A 275 (2007) 54.

[4] (a) A.J. Burke, Coord. Chem. Rev. 252 (2008) 170; (b) D. Chatterjee, Coord. Chem. Rev. 252 (2008) 176; (c) J. Muzart, J. Mol. Catal. A 276 (2007) 62.

[5] (a) K.-P. Ho, K.-Y. Wong, T. H. Chan, Tetrahedron 62 (2006) 6650; (b) A. Zimmer, D. Mönter, W. Reschetilowski, J. Appl. Electrochem. 33 (2003) 933.

[6] T. Osa, in: T. Osa (Ed.) New Challenges in Organic Electrochemistry 3.1, Gordon and Breach Publishers, Amsterdam, The Netherlands, 1998, p. 183. 
[7] Y. Shen., M. Atobe, W. Li, T. Nonaka, Electrochim. Acta 48 (2003) 1041.

[8] S. Torii, K. Uneyama, M. Ono, H. Tazawa, S. Matsunami, Tetrahedron Lett. 48 (1979) 4661.

[9] S.Torii, K. Uneyama, H. Tanaka, T. Yamanaka, T. Yasuda, M. Ono, Y. Kohmoto, J. Org. Chem. 46 (1981) 3312.

[10] R.Alkire, J. Köhler, J. Appl. Electrochem. 18 (1988) 405.

[11] D. Nematollahi, N. Akaberi, Molecules 6 (2001) 639.

[12] C. J. Pouchert, J. Behnke, The Aldrich Library of ${ }^{13} \mathrm{C}$ and ${ }^{1} \mathrm{H}$ FT NMR Spectra, Aldrich Chemical Company, St. Louis, USA, 1993, Vols. 1-3.

[13 (a) B. Bahramian, V. Mirkhani, M. Moghadam, S. Tangestaninejad, Appl. Catal. A Gen., 301 (2006) 169; (b) H. Zhang, S. Xiang, J. Xiao, C. Li, J. Mol. Cat. A 238 (2005) 175.

[14] (a) G. Kowalski, J. Pielichowski, M. Jasieniak, Appl. Catal. A Gen. 247 (2003) 295; (b)

A. Głuszyńska, I. Maćkowska, M.D. Rozwadowska, W. Sienniak, Tetrahedron: Asymmetry 15 (2004) 2499.

[15] (a) D. Lee, H. Bang, M.P. Suh, J. Mol. Catal. A Chem. 151 (2000) 71; (b) R. Ferreira, H. García, B. de Castro, C. Freire, Eur. J. Inorg. Chem. 21 (2005) 4272.

[16] M. A. Uguina, J.A. Delgado, A. Rodríguez, J. Carretero, D. Gómez-Díaz, J. Mol. Catal. A Chem. 256 (2006) 208.

[17] L. Albarella, D. Musumeci, D. Sica, Eur. J. Org. Chem. 5 (2001) 997.

[18] (a) L.F. Lima, L. Cardozo-Filho, P.A. Arroyo, H. Marquez-Alvarez, O.A.C. Antunes, React. Kinet. Catal. Lett. 84 (2005) 69; (b) S.P. Casuscelli, E. Herrero, N. Crivello, C. Perez, M.G. Egusquiza, C.I. Cabello, I.L. Botto, Catal. Today 107 (2005) 230.

[19] L.J. Schofield, O.J. Kerton, P. McMorn, D. Bethell, S. Ellwood, G. Hutchings,. J. Chem. Soc. Perkin Trans. 2 (2002) 1475. 
[20] (a) R.R.L. Martins, M.G.P.M.S. Neves, A.J.D.Silvestre, M.M.Q. Simões, A.M.S. Silva, A.C. Tomé, J.A.S. Cavaleiro, P. Tagliatesta, C. Crestini, J. Mol. Catal. A Chem. 172 (2001) 33; (b) W-K. Chan, W-Y. Yu, C-M. Che, M-K.Wong, J. Org. Chem. 68 (2003) 6576.

[21] S. Sakaguchi, Y. Nishiyama, Y.Ishii, J. Org. Chem. 61 (1996) 5307. 
Table 1 - Coulometric Data and Product Yields for Catalytic Oxidation of synthetic alkenes $(20 \mathrm{mM})$ in the presence of sodium bromide $(20 \mathrm{mM})$ in $\mathrm{MeCN} / \mathrm{H}_{2} \mathrm{O}(4: 1)$ at platinum electrodes.

\begin{tabular}{|c|c|c|c|c|c|c|c|}
\hline Entry & Substrate & $\begin{array}{l}\text { Current } \\
\text { density }^{\mathrm{a}} \\
\left(\mathbf{m A} / \mathbf{c m}^{2}\right)\end{array}$ & $\mathrm{F} / \mathrm{mol}^{\mathrm{b}}$ & $\begin{array}{c}\text { Conversion } \\
(\%)\end{array}$ & $\begin{array}{c}\text { Epoxide } \\
\text { yield } \\
\left(\eta_{m} / \%\right)\end{array}$ & $\begin{array}{l}\text { Current } \\
\text { efficiency } \\
\left(\eta_{c} / \%\right)\end{array}$ & Product \\
\hline 1 & 1 & 33 & 2 & 100 & 27 & 21 & 4 \\
\hline 2 & $1^{\mathrm{c}}$ & 33 & 2 & 100 & 57 & 74 & 4 \\
\hline 3 & 1 & 66 & 2 & 100 & 79 & 38 & 4 \\
\hline 4 & 8 & $33^{\mathrm{d}}$ & 5 & 66 & 23 & 47 & 9 \\
\hline 5 & 8 & $33^{\mathrm{d}}$ & 8 & 84 & 24 & 50 & 9 \\
\hline 6 & 8 & $3.3^{\mathrm{d}}$ & 4 & 82 & 38 & 67 & 9 \\
\hline 7 & 11 & 33 & 5 & 100 & 30 & 29 & 12 \\
\hline
\end{tabular}


Table 2 - Coulometric Data and Product Yields for Catalytic Oxidation of natural terpenes $(40 \mathrm{mM})$ in the presence of sodium bromide $(40 \mathrm{mM})$ in $\mathrm{MeCN} / \mathrm{H}_{2} \mathrm{O}(4: 1)$ at a current density of $3.3 \mathrm{~mA} / \mathrm{cm}^{2}$ at platinum electrodes ${ }^{\mathrm{a}}$.

\begin{tabular}{|c|c|c|c|c|c|c|}
\hline Entry & Substrate & $\mathrm{F} / \mathrm{mol}^{\mathrm{b}}$ & $\begin{array}{c}\text { Conversion } \\
(\%)\end{array}$ & $\begin{array}{c}\text { Epoxide } \\
\text { yield } \\
\left(\eta_{m} / \%\right)\end{array}$ & $\begin{array}{l}\text { Current } \\
\text { efficiency } \\
\left(\eta_{c} / \%\right)\end{array}$ & Product \\
\hline 1 & 13 & $2^{c, d}$ & 83 & 25 & 25 & 14 \\
\hline 2 & 13 & $3^{c}$ & 83 & 37 & 41 & 14 \\
\hline 3 & 13 & 2 & 93 & 34 & 37 & 14 \\
\hline 4 & 16 & 2 & 86 & 40 & 45 & 17 \\
\hline 5 & 18 & 3 & 53 & 43 & 65 & 19 \\
\hline 6 & 18 & 5 & 73 & 24 & 23 & 20 \\
\hline 7 & 21 & 2 & 88 & 32 & 27 & 22 \\
\hline 8 & 23 & 2 & 82 & 41 & 52 & 24 \\
\hline 9 & 25 & 2 & 83 & 56 & 61 & 26 \\
\hline
\end{tabular}

${ }^{\mathrm{a}}$ Platinum anode $\left(\mathrm{A}=2.5 \times 2.5 \mathrm{~cm}^{2}\right)$; ${ }^{\mathrm{b}}$ Number of faradays per molecule of the starting material; ${ }^{\mathrm{c}}$ Platinum anode $\left(\mathrm{A}=1.1 \times 1.1 \mathrm{~cm}^{2}\right)$; ${ }^{\mathrm{d}}$ Current density equal to $33 \mathrm{~mA} \mathrm{~cm}{ }^{-2} ; \eta_{\mathrm{m}}=$ [Obtained mass of epoxide $(\mathrm{g}) /$ Theoretical mass of epoxide $(\mathrm{g})] \times 100 ; \eta_{\mathrm{c}}=$ [moles of product obtained by a charge $c /$ Theoretical moles of product obtained by a charge $c] \times 100$; Conversion $(\%)=[($ initial moles of substrate - moles of substrate at the end of reaction) / initial moles of substrate] $\times 100$. 
Table 3 - 1-methyl-4-(prop-1-en-2-yl)-7-oxa-bicyclo[4.1.0]heptane (14) yields obtained re-using the solution of $\mathrm{NaBr}$ of the expoxidation of 1-methyl-4(prop-1-en-2-yl)cyclohex-1-ene (Table 2, entry 3) with current density of 3.3 $\mathrm{mA} \mathrm{cm}$ at platinum anode $(2.5 \mathrm{~cm} \times 2.5 \mathrm{~cm})$. [1-methyl-4-(prop-1-en-2yl)cyclohex-1-ene] $=40 \mathrm{mM}$.

$$
\text { Run 1-methyl-4-(prop-1-en-2-yl)-7-oxa-bicyclo[4.1.0]heptane }
$$

\begin{tabular}{|c|c|c|}
\hline & $\eta_{\mathbf{m}}$ & $\eta_{c}$ \\
\hline 1 & 39 & 34 \\
\hline 2 & 35 & 31 \\
\hline 3 & 29 & 21 \\
\hline 4 & 20 & 12 \\
\hline
\end{tabular}

$\eta_{\mathrm{m}}=[$ Obtained mass of epoxide $(\mathrm{g}) /$ Theoretical mass of epoxide $(\mathrm{g})] \times 100 ; \eta_{\mathrm{c}}=[$ moles of product obtained by a charge $c /$ Theoretical moles of product obtained by a charge $c] \times 100$; Conversion $(\%)=[($ initial moles of substrate - moles of substrate at the end of reaction $) /$ initial moles of substrate $] \times 100$. 


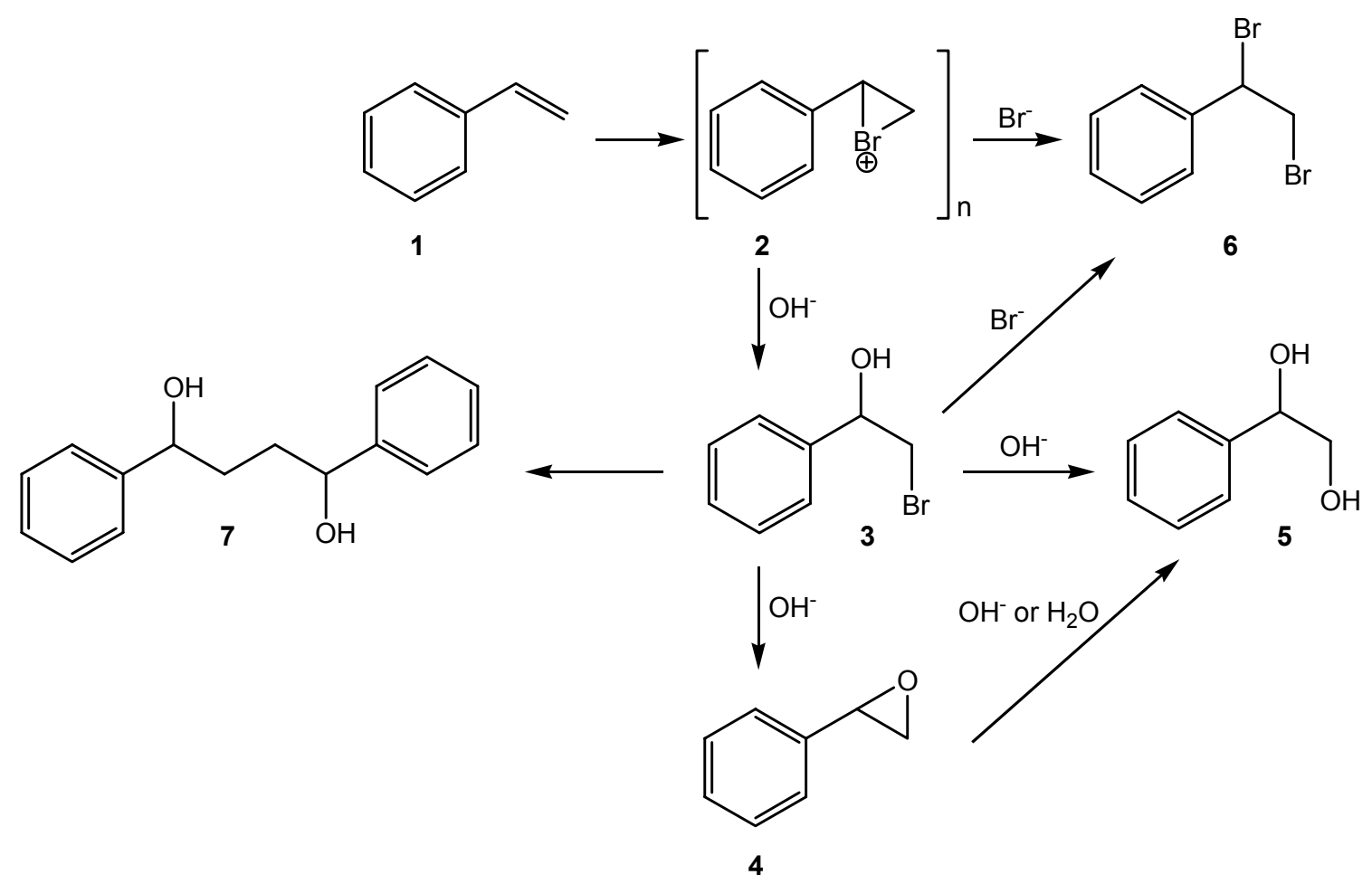

Figure 1 - The proposed mechanism for styrene electroepoxidation mediated by $\mathrm{NaBr}$ and for the identified by-products. 


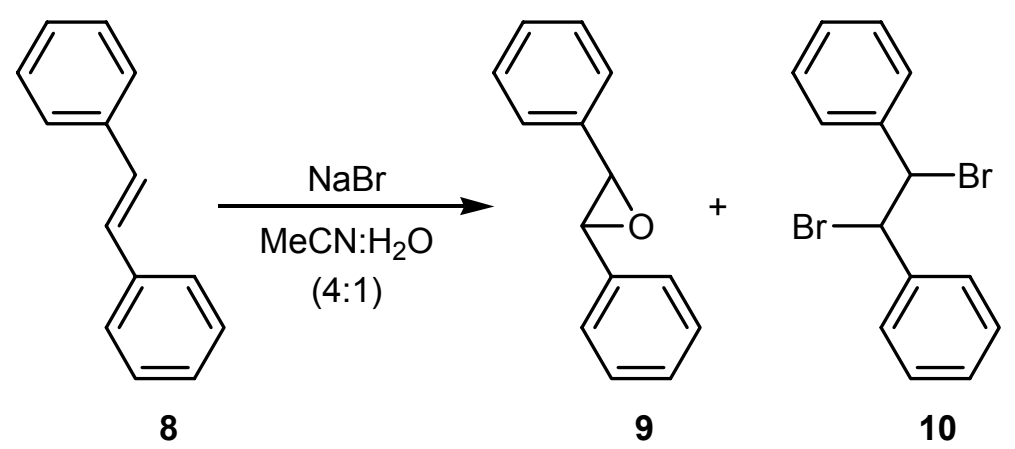

Figure 2 - Electroepoxidation of $(E)$-1,2-diphenylethene 
<smiles>CC=Cc1ccccc1</smiles>

11

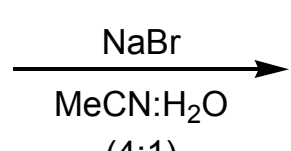

$(4: 1)$<smiles>CC1OC1c1ccccc1</smiles>

12

Figure 3 - Electroepoxidation of 1-[(E)-prop-1-enyl]benzene. 


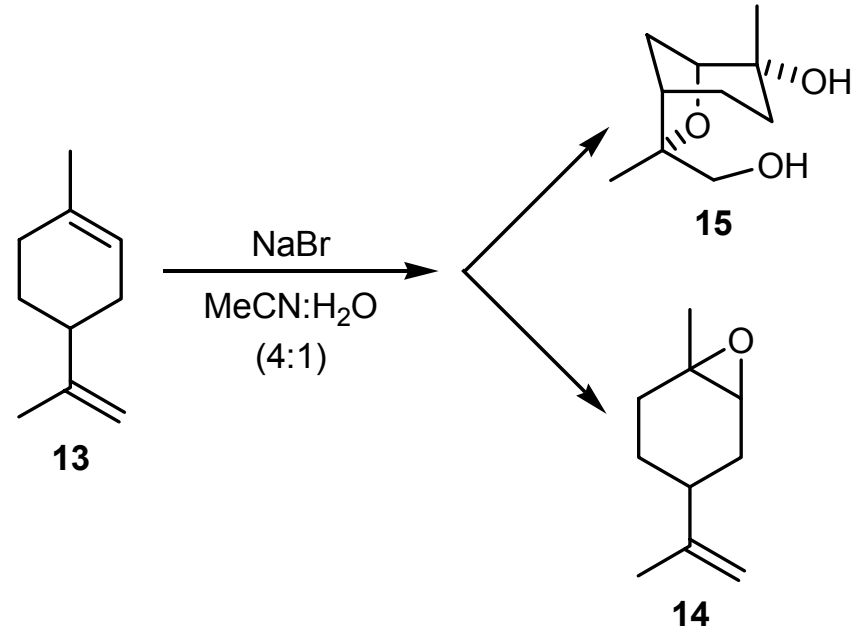

Figure 4 - Electroepoxidation of 1-methyl-4-(prop-1-en-2-yl)cyclohex-1-ene. 
<smiles>CC1=CCC(=C(C)C)CC1</smiles>

16

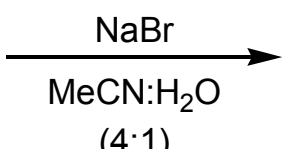

(4:1)<smiles>CC1(C)OC12CC=CCC2</smiles>

17

Figure 5 - Electroepoxidation of 1-methyl-4-(propan-2-ylidene)cyclohex-1-ene. 


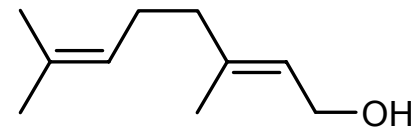

18

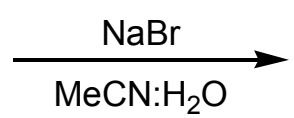

$(4: 1)$
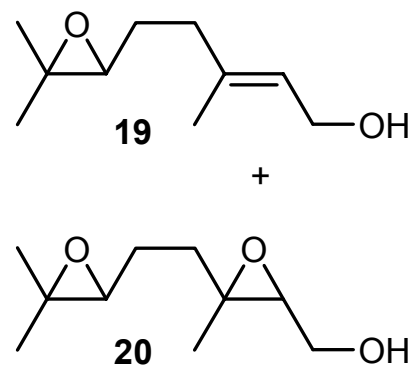

Figure 6 - Electroepoxidation of (E)-3,7-dimethylocta-2,6-dien-1-ol. 


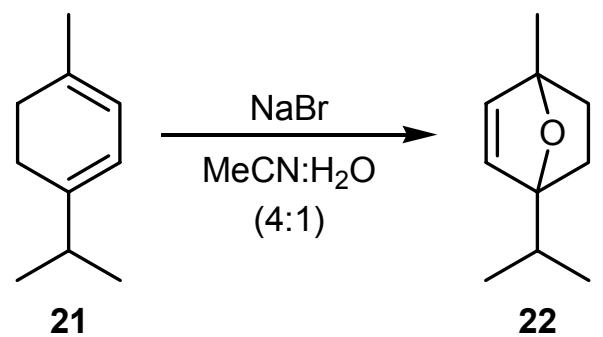

Figure 7 - Electroepoxidation of 1-isopropyl-4-methylcyclohexa-1,3-diene. 


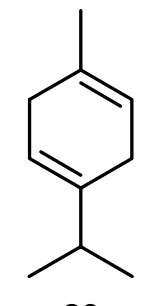

23

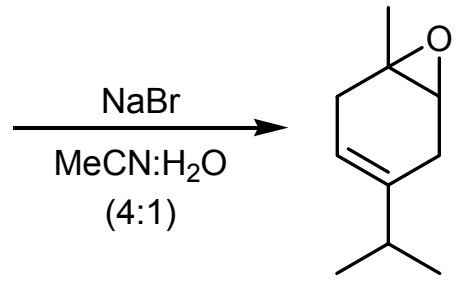

24

Figure 8 - Electroepoxidation of 1-isopropyl-4-methylcyclohexa-1,4-diene. 
<smiles>CC1=CCC(C(C)(C)O)CC1</smiles>

25

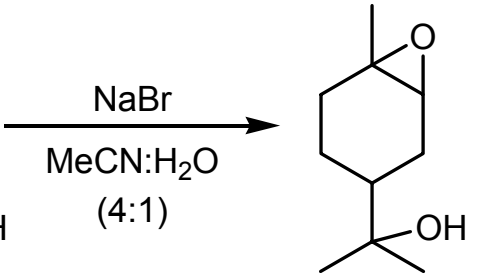

26

Figure 9 - Electroepoxidation of 2-(4-methylcyclohex-3-enyl)propan-2-ol. 